\title{
ANATOMY OF NORMAL AND HYPERHYDRIC SUNFLOWER SHOOTS REGENERATED In vitro
}

\author{
Fauguel, C.M. ${ }^{1}$, Vega, T.A. ${ }^{1}$, Nestares, G. ${ }^{*}$, Zorzoli, R. ${ }^{1,2}$, \\ and Picardi, L.A. ${ }^{1,2}$ \\ ${ }^{1}$ Cátedra de Genética, Facultad de Ciencias Agrarias, UNR. Campo Experimental \\ “J. F. Villarino", C.C. 14, S 2125 ZAA Zavalla, Argentina \\ ${ }^{2}$ CIUNR - Consejo de Investigaciones de la Universidad Nacional de Rosario, \\ Rosario, Argentina
}

Received: January 22, 2007

Accepted: March 24, 2008

\begin{abstract}
SUMMARY
Hyperhydricity is a morphological and physiological disorder affecting plants regenerated in vitro. This malformation is associated with excessive hydration and abnormal shoot morphogenesis such as glassy water-soaked appearance of shoots. This undesirable phenomenon is a frequent problem in sunflower tissue culture systems and has been described by visual symptoms but there is no information on the anatomic structure of the affected shoots. In this paper we describe anatomic features of normal and hyperhydric sunflower shoots regenerated in vitro. The hyperhydric shoots were classified in four categories according to different abnormalities observed at the morphological level. The anatomic structure of leaves and stems of normal shoots did not differ from control seedlings. In contrast, hyperhydric shoots presented various anatomic defects, such as reduction of palisade parenchyma, an increase in cellular volume, hypolignification of vascular system and hypertrophy of cortical and pith parenchyma. In addition, a crescent disorganization at the anatomic level was observed among the different types of hyperhydric shoots. This study provides a characterization of the anatomic responses induced by hyperhydration in tissue culture regenerated sunflower plants.
\end{abstract}

Key words: Helianthus annuus L., direct organogenesis, hyperhydricity, plant anatomy

\section{INTRODUCTION}

The sunflower (Helianthus annuus L.) is one of the most important oilseed crops in the world. In addition to conventional breeding methods, biotechnological approaches like tissue culture techniques are essential for sunflower improvement. Successful regeneration by organogenesis or by somatic embryogenesis has been reported in recent years (Bidney and Scelonge, 1997). Nevertheless, there are differ-

* Corresponding author: e-mail: gnestare@unr.edu.ar 
ent problems in plant regeneration such as precocious flowering, hyperhydricity and poor rooting (Witzrens et al., 1988; Nestares et al., 1996; Baker et al., 1999). The special conditions during in vitro culture, such as low level of light, high relative humidity atmosphere and ample sugar and nutrients, results in the formation of plantlets of abnormal morphology, anatomy and physiology (Pospíšilová, 1999; Hazarika, 2006). Hyperhydicity, (formerly called vitrification) is a physiological malformation affecting clonally propagated plants generated under tissue culture conditions (Debergh et al., 1992). This physiological malformation is associated with chlorophyll deficiency, poor lignification, and excessive hydration of tissues, which result in malconformed plantlets that cannot survive ex vitro conditions after transplanting (Kevers et al., 2004). Up to $60 \%$ of affected plants fail to acclimatize (Pâques and Boxus, 1987a), thereby limiting the application of in vitro techniques. The affected plants appear glassy, water-soaked, "translucent", succulent, or "fleshy". These plants also have reduced or retarded growth and thickened and malformed stem and leaves. As stated by Ziv (1991) this phenomenon, traditionally defined by visual symptoms, must include changes initiated before the visible symptoms became apparent, thus, some of the characteristics of the leaf anatomy and morphology of in vitro-cultured shoots that differ markedly from leaves produced ex vitro might be considered to be precursors of the hyperhydric condition. Investigations undertaken on this subject in the last 10 years do not allow yet a thorough understanding of the mechanisms inducing this phenomenon. This is due to a great number of involved factors and their diversity (Pâques and Boxus, 1987a). Moreover, hyperhydricity involves multiple factors that, depending on the specific physiological responses to culture conditions and the species studied, are expressed in various degrees of abnormal morphogenesis (Ziv, 1991). In spite of the numerous studies that reported the occurrence of hyperhydric plants during in vitro regeneration in sunflower, no information about the anatomic characteristics in affected shoots has been reported. The aim of this work was to study the anatomic features of normal and hyperhydric sunflower stems and leaves regenerated in vitro and to compare them with those of control plants.

\section{MATERIALS AND METHODS}

\section{Plant material}

The inbred line HA300B from the Germplasm Bank of the Estación Experimental Agropecuaria (EEA), Instituto Nacional de Tecnología Agropecuaria (INTA) Pergamino, Argentina was used in this study.

\section{In vitro culture}

Seeds without pericarps were surfaced-sterilized for $30 \mathrm{~s}$ in $98 \%$ ethanol, soaked $15 \mathrm{~min}$ in 5\% sodium hypochlorite, and then rinsed three times in sterilized distilled water. The basal part of the cotyledon deprived of axillary meristem was 
used as explant. The regeneration medium contained salts, vitamins and ironchelates according to Murashige and Skoog (1962), 5.71 $\mu \mathrm{M}$ indol-3-acetic-acid (IAA), $9.29 \mu \mathrm{M}$ kinetin (KIN). The culture medium also contained $6.10 \mu \mathrm{M}$ glutamine and the $\mathrm{pH}$ was adjusted to 6.0 prior to autoclaving. Cultures were grown at $25 \pm 1^{\circ} \mathrm{C}$ under a 12 -h photoperiod $\left(50 \mu \mathrm{M}\right.$ quanta $\left.\mathrm{m}^{-2} \mathrm{~s}^{-1}\right)$ for 30 days.

Control plants were obtained from seeds germinated on petri dishes and then grown under greenhouse conditions to four fully expanded leaves.

\section{Histology}

Shoots and leaves of in vitro plantlets (normal and hyperhydric) and those cultivated in greenhouse were fixed in $3 \%$ glutaraldehyde, buffered with $0.05 \mathrm{M}$ phosphate buffer at $\mathrm{pH}=7.2$. The samples were then dehydrated through ethanol series and embedded in paraffin using standard procedure. Sections $15 \mu \mathrm{m}$ thick were cut on a rotary Minot type microtome and stained with safranine followed by fast green (Ruzin, 1999).

\section{RESULTS}

\section{Macroscopic features}

During the regeneration stage, direct organogenesis of normal and hyperhydric shoots was observed on cotyledonary explants. The hyperhydric shoots were classified in four categories according to different abnormalities observed at the morphological level: a) translucent shoots, with leaves of humid aspect, transparent, and of light green color; b) thickened shoots, with short internodes and thick stems; c) twisted shoots, with rolled leaves so that only the lower epidermis could be seen; and d) succulent shoots, with the highest level of hyperhydricity, deformed aspect, fleshy, easily breakable, with excessive hydration in all tissues.

The characteristics of the seedlings (control plants) corresponded to those described for the species (Seiler, 1997). All normal shoots regenerated in vitro presented similar characteristics to those described for seedlings but in general they did not develop radicular system on the regeneration medium.

\section{Anatomic features}

Seedlings. The epidermis appeared as a single layer of cells on both leaf surfaces. Mesophyll was dorsiventral with 1-2 rows of palisade cells and spongy parenchyma with some intercellular spaces and abundant chloroplasts. Vascular bundles were collateral with well lignified vessels (Figure 1A). The stem epidermis displayed a single layer of cells and few stomata. The cortex contained numerous collateral vascular bundles (Figure 1B).

Normal shoots regenerated in vitro. The anatomic characteristics of leaves and stems from normal shoots regenerated in vitro were similar to those of control seedlings (Figure 1C, D). 

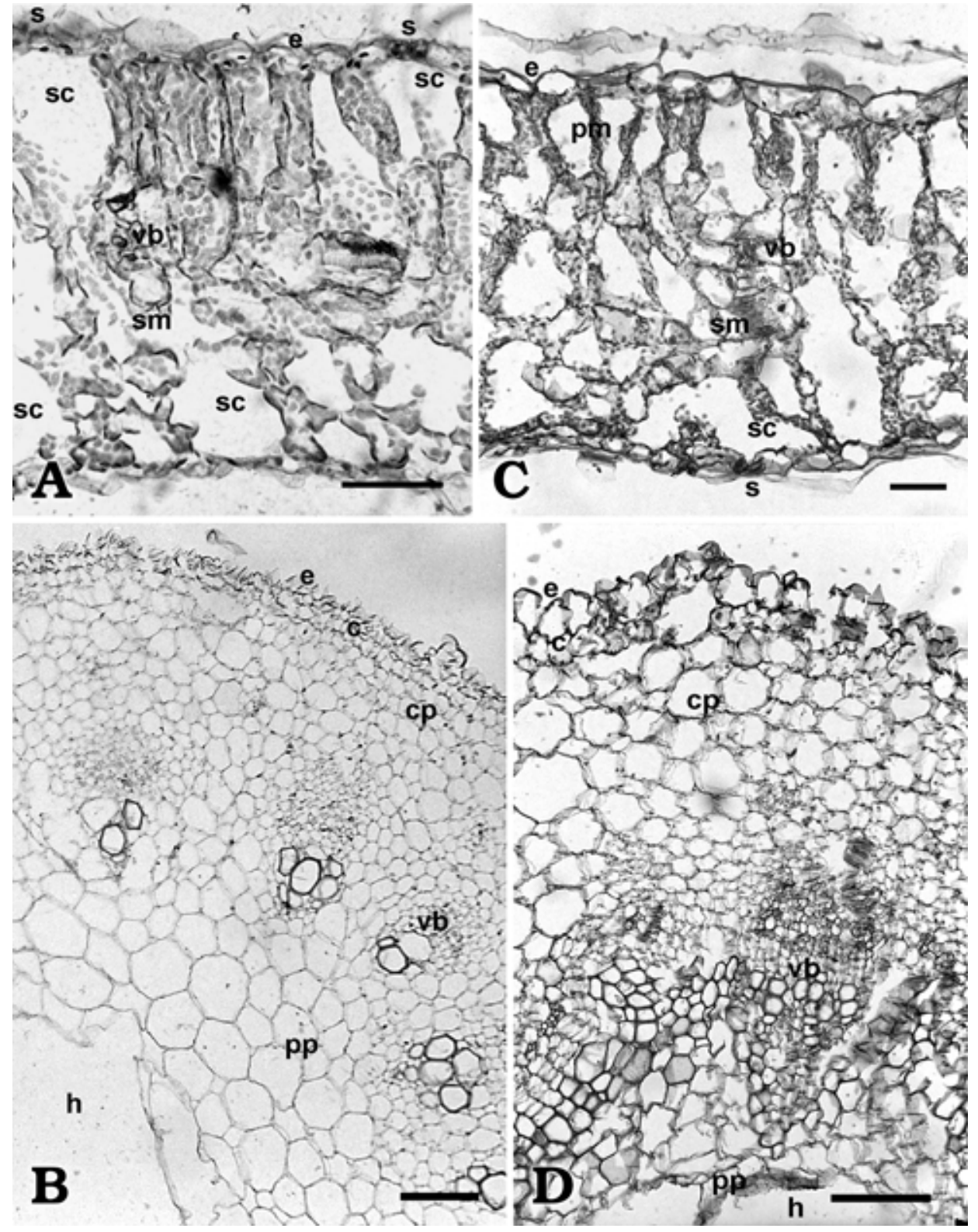

Figure 1: (A) Transverse section of seedling leaves. (B) Transverse section of seedling stem. (C) Transverse section of normal leaves regenerated in vitro. (D) Transverse section of normal stem regenerated in vitro. c, collenchyma; $c p$, cortical parenchyma; e, epidermis; $h$, hole; pm, palisade mesophyll; pp, pith parenchyma; $s$, stomata; sc, subestomatal cavity; sm, spongy mesophyll; vb, vascular bundle. Scale bar: $50 \mu \mathrm{m}(A, C) ; 100 \mu \mathrm{m}(B, D)$. 
Hyperhydric shoots regenerated in vitro. Leaf epidermis of the translucent shoots was with a single layer of cells and a palisade mesophyll with 1-2 rows of cells. Spongy parenchyma was organized and presented numerous organized vascular bundles and chloroplasts. Intercellular spaces were not observed in this tissue, resulting in a highly compact mesophyll (Figure 2A). Thickened shoot leaves presented lax and disorganized mesophyll and an increase in the cellular volume (Figure 2B).
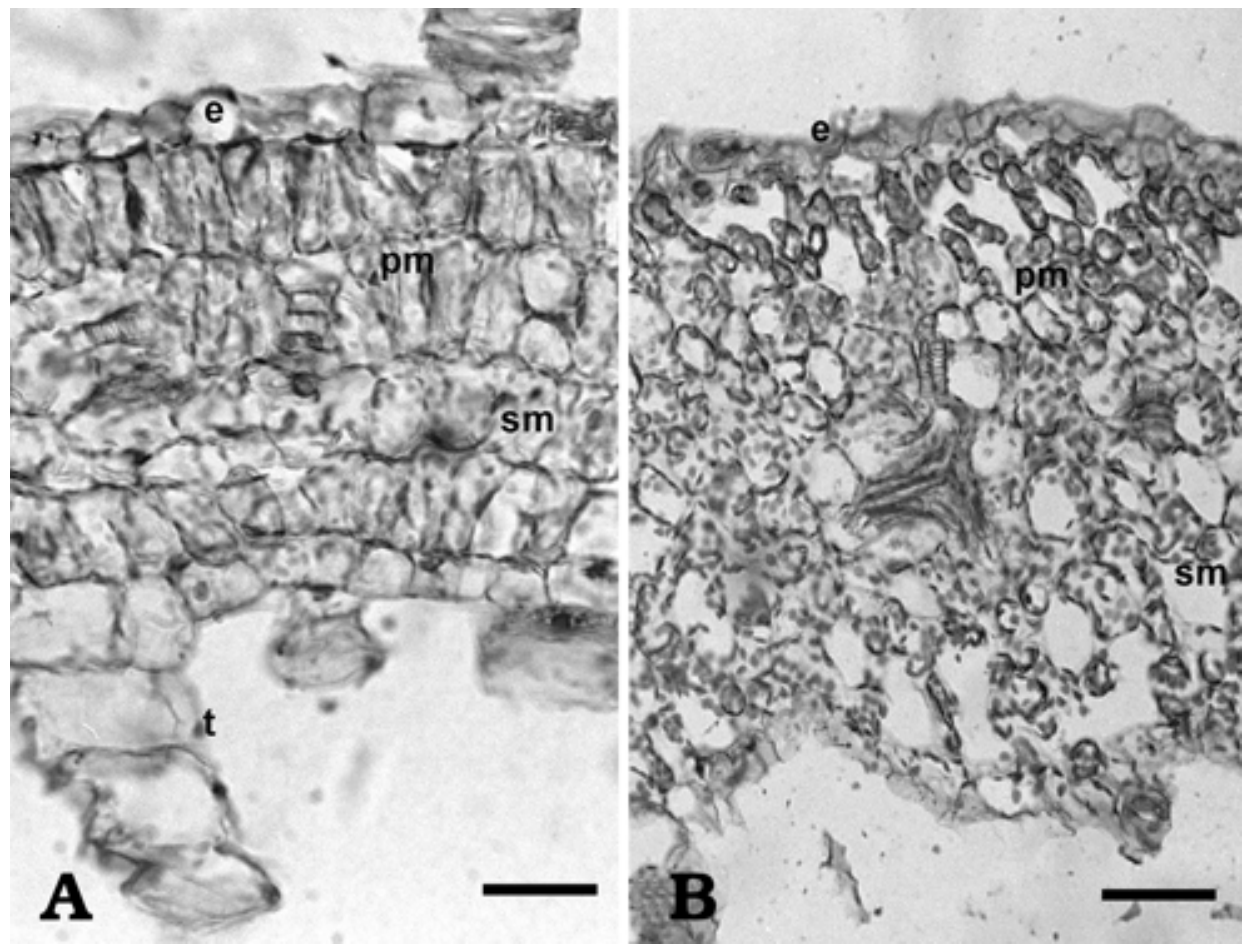

Figure 2: (A) Transverse section of translucent leaves regenerated in vitro. (B) Transverse section of thickened leaves regenerated in vitro. e, epidermis; pm, palisade mesophyll; sm, spongy mesophyll; $t$, trichome. Scale bar: $50 \mu m$.

Figure $3 A$ shows a transversal section of twisted shoot leaves where the curved ends could be seen. The lack of clear differentiation between palisade and spongy parenchyma and an increase in the cellular volume was observed for this type of shoot leaves. Also the vascular bundles were disorganized with hypolignification of the vascular system (Figure 3B). Leaves of succulent shoots showed severe anatomic malformations. They either presented a very thin palisade tissue or lacked it all together. Most of the unorganized mesophyll consisted of spongy parenchyma with some intercellular spaces. Vascular bundles were few and lacked the typical arrangement of a normal shoot (Figure 3C). 

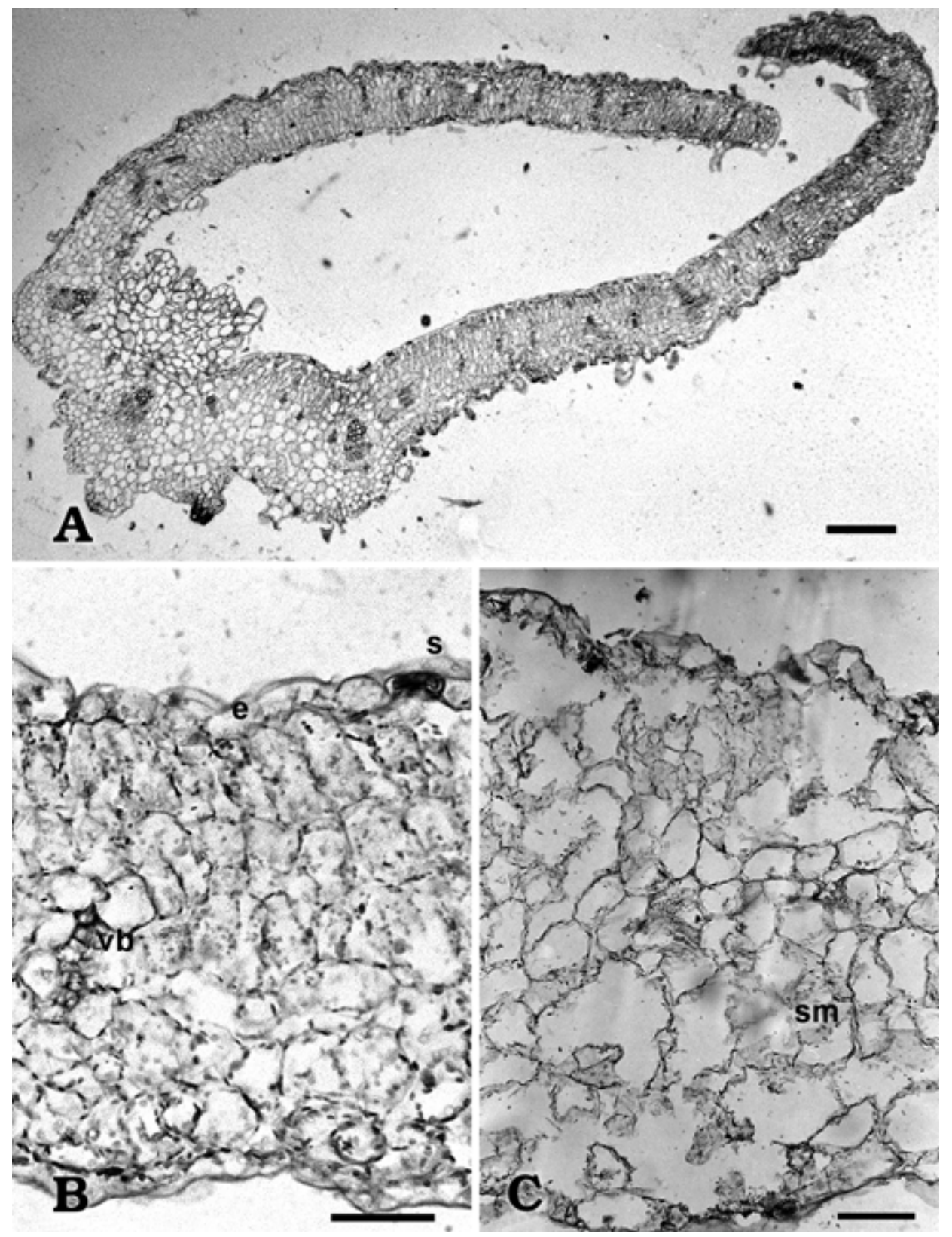

Figure 3: (A) General view of transverse section of twisted leaves regenerated in vitro. (B) Mesophyll of twisted leaves regenerated in vitro. (C) Transverse section of succulent leaves regenerated in vitro. e, epidermis; pm, palisade mesophyll; sm, spongy mesophyll; vb, vascular bundle. Scale bar: $250 \mu \mathrm{m}(\mathrm{A}) ; 100 \mu \mathrm{m}(B, C)$. 
Stems of hyperhydric shoots displayed hypertrophy of cortical and pith parenchyma and hypolignification of the vascular system. The cells were surrounded by thin, non-rigid walls (Figure 4). Succulent shoots regenerated in vitro did not present evident stem.
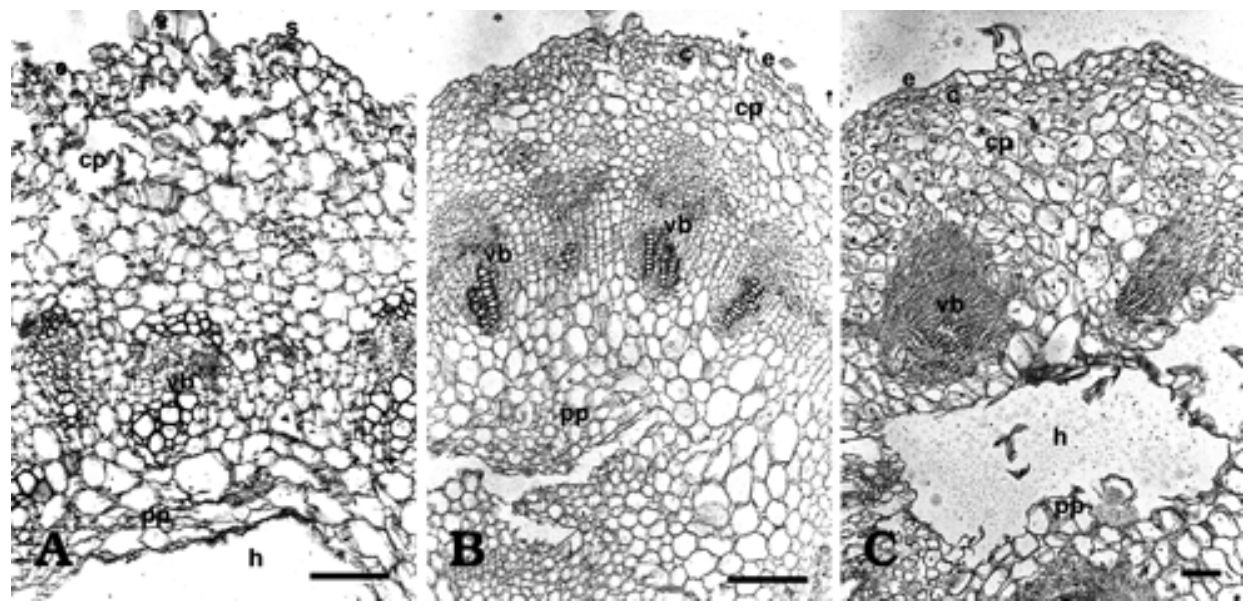

Figure 4: (A) Transverse section of translucent stem regenerated in vitro. (B) Transverse section of thickened stem regenerated in vitro. (C) Transverse section of succulent stem regenerated in vitro. $c$, collenchyma; $c p$, cortical parenchyma; e, epidermis; $h$, hole; pp, pith parenchyma; s, stomata; vb, vascular bundle. Scale bar: $100 \mu \mathrm{m}$.

\section{DISCUSSION}

The leaves and stems of normal in vitro plantlets were quite similar to those of the control sunflower plants. However, the anatomic structure of hyperhydrated shoots differed markedly from the seedlings. These shoots showed the characteristic anatomic features. In general, there was a reduction in the number of palisade cell layers; the palisade cells resembled more those of spongy parenchyma with an increase in cellular volume. The vascular system of the hyperhydrated leaves was less developed than in normal leaves and the xylem bundles and phloem fibers were less lignified.

Similarly to our results, reduction of palisade parenchyma in hyperhydrated leaves has been described for affected shoots of Cynara scolymus (Debergh et al., 1981), Dianthus cariophyllus (Ziv et al., 1983) and Castanea sativa (Vieitez et al., 1985). Also, a general increase in cellular volume has often been observed for hyperhydric leaves in several species (Vieitez et al., 1985, Pâques and Boxus, 1987b, Apóstolo and Llorente, 2000). Anomalous anatomy is manifested mainly in leaves and to a lesser extent in stems and roots (Ziv, 1991). As found with other species, the hyperhydrated sunflower stems exhibited hypertrophy of cortical and pith 
parenchyma and hypolignification of vascular system (Kevers and Gaspar, 1985; Vieitez et al., 1985).

Shoot hyperhydricity is a frequent problem in sunflower tissue culture systems. Plant loses during acclimatization are often recorded because affected shoots fail to root and/or to survive transplanting (Witrzens et al., 1988; Knittel et al., 1991; Ceriani et al., 1992; Nestares et al., 1996; Baker et al., 1999). Although efforts have been made in this species to control this undesirable phenomenon, at present it was reduced but not avoided (Mayor et al., 2003). This paper is the result of the first study on the anatomic features of normal and hyperhydric sunflower plants grown under in vitro conditions. The different categories classified at the morphological level presented distinctive anatomic features. In addition, a crescent disorganization at the anatomic level was observed from translucent to succulent shoots, while thickened and twisted shoots appeared as intermediate abnormal types. Anomalous anatomy described for leaves of hyperhydric regenerated shoots could be useful to predict, by histological examination, which plantlets would survive the acclimatization stage and consequently reduce the resources invested in the ex vitro stage.

\section{ACKNOWLEDGMENTS}

The authors acknowledge Dr. Susana Gattuso for helpful discussions and assistance. Special thanks to Dr. Osvaldo Di Sapio for help with photographs and to Dr. Emilce Prado for her assistance in translating the summary into French. Financial support for this project was provided by ANPCyT-FONCYT (PICT 2002 № 08-10832).

\section{REFERENCES}

Apóstolo, N. and Llorente, B., 2000. Anatomy of normal and hyperhydric leaves and shoots of in vitro grown Simmondsia chinensis (link) Schn. in vitro cell. dev. Biol. Plant 36: 243249.

Baker, C.M., Muñoz-Fernandez, N., and Carter, C.D., 1999. Improved shoot development and rooting from mature cotyledons of sunflower. Plant Cell Tissue and Organ Cult. 58: 39-49.

Bidney, D.L. and Scelonge, C.J., 1997. Sunflower biotechnology. In: Schneiter, A.A. (ed.): Sunflower Technology and Production. ASA-CSSA-SSSA Madison, Wisconsin, USA, pp. 559-593.

Ceriani, M.F., Hopp, H.E., Hahne, G. and Escandón, A.S., 1992. Cotyledon: An explant for routine regeneration of sunflower plants. Plant Cell Physiol. 33: 157-164.

Debergh, P., Harbaoui, R. and Lemeur, R., 1981. Mass propagation of glove artichoke (Cynara scolymus): evaluation of different hypotheses to overcome vitrification with special reference to water potential. Physiol. Plant. 53: 181-187.

Debergh, P.C., Aitken-Christie, J., Cohen, D., Grout, B., von Arnold, S., Zimmerman, R., and Ziv, M., 1992. Reconsideration of the term < vitrification $>$ as used in micropropagation. Plant Cell Tissue and Organ Cult. 30: 135-140.

Hazarika, B.N., 2006. Morpho-physiological disorders in in vitro culture of plants. Scientia Hort. 108: 105-120. 
Kevers, C. and Gaspar, T., 1985. Soluble membrane and wall peroxidases, phenylalanine ammonialyase, and lignine changes in relation to vitrification of carnation tissues cultured in vitro. J. Plant Physiol. 118: 41-48.

Kevers, C., Franck, T., Strasser, R., Dommes, J. and Gaspar, T., 2004. Hyperhydricity of micropropagated shoots: a typically stress-induced change of physiological state. Plant Cell Tissue and Organ Cult. 77: 181-191.

Knittel, N., Escandón, A.S. and Hahne, G., 1991. Plant regeneration at high frequency from mature sunflower cotyledons. Plant Sci. 73: 219-226.

Mayor, M.L., Nestares, G., Zorzoli, R. and Picardi, L.A., 2003. Reduction of hyperhydricity in sunflower tissue culture. Plant Cell Tissue and Organ Cult. 72: 99-103.

Murashige, T. and Skoog, F., 1962. A revised medium for rapid growth and bioassays with tobacco tissue cultures. Physiol. Plant. 15: 473-497.

Nestares, G., Zorzoli, R., Mroginski, L. and Picardi, L., 1996. Plant regeneration from cotyledons derived from mature sunflower seeds. Helia 19: 107-112.

Pâques, M. and Boxus, P., 1987a. Vitrification: Review of literature. Acta Hort. 212: 155-166.

Pâques, M. and Boxus, P., 1987b. A model to learn "vitrification", the rootstock apple M.26 present results. Acta Hort. 212: 193-210.

Pospíšilová, J., Tichá, I., Kadleček, P., Haisel, D. and Plzáková, Š., 1999. Acclimatization of micropropagated plants to ex vitro conditions. Biol. Plant. 42: 481-497.

Ruzin, S.E., 1999. Plant microtechnique and microscopy. Oxford University Press, New York.

Seiler, G.J., 1997. Anatomy and morphology of sunflower. In: Schneiter, A.A. (ed.): Sunflower Technology and Production., ASA-CSSA-SSSA Madison, Wisconsin, USA, pp. 67-111.

Vieitez, A.M., Balléster, A., San-Jose, M.C. and Vieitez, E., 1985. Anatomic and chemical studies of vitrified shoots of chestnut regenerated in vitro. Physiol. Plant. 65: 177-184.

Wirtzens, B., Scowcroft, W.R., Downes, R.W. and Larkin, P.J., 1988. Tissue culture and plant regeneration from sunflower (Helianthus annuus) and interespecific hybrids (H. tuberosus $\mathrm{x}$ H. annuus). Plant Cell Tissue and Organ Cult. 13: 61-76.

Ziv, M., 1991. Vitrification: morphological and physiological disorders of in vitro plants. In: Debergh, P.C., Zimmerman, R.H. (ed.): Micropropagation: Technology and Application. Kluwer Academic, Dordrecht, pp. 49-69.

Ziv, M., Meir, G. and Halevy, A. H., 1983. Factors influencing the production of hardened glaucous carnation plantlets in vitro. Plant Cell Tissue and Organ Cult. 2: 55-60.

\title{
ANATOMÍA DE VÁSTAGOS DE GIRASOL NORMALES E HIPERHÍDRICOS REGENERADOS in vitro
}

\author{
RESUMEN
}

La hiperhidricidad es un desorden morfológico y fisiológico que afecta a las plantas regeneradas in vitro. Esta malformación está asociada a una excesiva hidratación y a la morfogénesis anormal de vástagos de apariencia vítrea y húmeda. Este fenómeno indeseable es un problema frecuente en los sistemas de cultivo in vitro en girasol y ha sido descrito por síntomas visuales pero no existe información acerca de la estructura anatómica de los vástagos afectados. En este trabajo se describe la anatomía de vástagos de girasol normales e hiperhídricos regenerados in vitro. Los vástagos hiperhídricos se clasificaron en cuatro categorías de acuerdo a las diferentes anormalidades observadas a nivel morfológico. La estructura anatómica de hojas y tallos de los vástagos normales no difirió de la de las plántulas obtenidas de semilla (control). En contraste, los vástagos hiperhídricos presentaron varios defectos anatómicos tales como reducción del parénquima en empalizada, un incremento en el volumen celular, hipolignificación del sistema vascular e hipertrofia del parénquima cortical y medular. Se observó además una desorganización anatómica creciente entre los diferentes tipos de vástagos hiperhídricos. Este estudio provee una caracterización de las respuestas anatómicas inducidas por hyperhidratación en plantas regeneradas in vitro en esta especie. 


\title{
ANATOMIE DE POUSSES DE TOURNESOL REGENEREES in vitro, NORMAUX ET HYPERHYDRIQUES
}

\author{
RÉSUMÉ
}

L'hyperhydricité est un désordre morphologique et physiologique qui affecte des plantes régénérées in vitro. Ce défaut est associé à une hydratation excessive des cellules et une morphologie anormale qui donne aux jeunes pousses une apparence vitrifiée. Ce phénomène non souhaitable est un problème fréquent dans les systèmes de culture in vitro de tournesol et a été décrit d'après les symptômes visibles à l'oeil nu mais il n'y a pas d'information sur l'anatomie des pousses affectées. Dans ce travail, nous comparons les caractéristiques anatomiques de pousses à l'apparence normale ou hyperhydrique après régénération in vitro. Les pousses hyperhydriques ont été classées en quatre catégoriques selon différentes anormalités observées au niveau morphologique. La structure anatomique des feuilles et des tiges de pousses normales ne diffère pas de celle de plantules issues de graines. Par contre, les pousses hyperhydriques présentent plusieurs défauts anatomiques, telle la diminution du parenchyme palissadique, l'augmentation du volume cellulaire, la mauvaise lignification du système vasculaire et l'hypertrophie du parenchyme cortical et lacuneux. Par ailleurs, nous avons observé une désorganisation croissante au niveau anatomique parmi les différents types de pousses hyperhydriques. Cette étude apporte une caractérisation des réponses anatomiques induites par l'hyperhydratation chez les plantes de cette espèce régénérées par culture in vitro. 